\title{
Correction to: Organizing Smart Buildings and Cities
}

Elisabetta Magnaghi, Véronique Flambard, Daniela Mancini, Julie Jacques, and Nicolas Gouvy

Correction to:

E. Magnaghi et al. (eds.), Organizing Smart Buildings and Cities, Lecture Notes in Information Systems and Organisation 36, https://doi.org/10.1007/978-3-030-60607-7

In the original version of the book, the following belated corrections have been incorporated:

In Chapters 2 and 3 titled "Smart Cities: A Response to Wicked Problems" and "Big Data: An Introduction to Data-Driven Decision Making", respectively, the affiliation of the authors "Peter B. Duncan and David A. Edgar" has been changed from "Lancashire School of Business and Enterprise, University of Central Lancashire, Preston, UK" to "Department of Business and Management, Glasgow Caledonian University, UK". This has been corrected in the updated version. 